\title{
Decision making in organisations hostile to knowledge sharing*
}

\author{
Snejina Michailova, Kenneth Husted ${ }^{* *}$
}

This paper focuses on some of the specificities of decision making in Russian organisations. These companies usually have a highly centralized decisionmaking. Paradoxically, Russian firms are also known for their relatively high level of hostility towards knowledge sharing. Both characteristics constitute a dangerous combination for strategic decision-making processes in the organisations and their ability to commit resources to adequate actions. On the basis of 53 interviews in 25 companies over the last six years, this paper analyses the interface between different dimensions of knowledge sharing hostility and the consequences these have for strategic decision making.

Der Aufsatz befasst sich mit einigen Merkmalen der Entscheidungsfindung in russischen Organisationen. Diesbezügliche Strukturen in Unternehmen sind normalerweise sehr stark. Paradoxerweise sind russische Firmen auch für ihre Einstellung gegen Informationsaustausch bekannt. Beide Merkmale stellen eine gefährliche Kombination für strategische Entscheidungsfindungsprozesse und für die Allokation von Ressourcen dar. Auf der Basis von 53 Interviews in 25 Firmen in den letzten 6 Jahren analysiert der Aufsatz das Interface zwischen verschiedenen Dimensionen der Einstellung gegen Informationsaustausch und den darausfolgenden Konsequenzen für die strategische Entscheidungsfindung.

Keywords: Russian organisations / knowledge sharing hostility / strategic decision making

\footnotetext{
* Manuscript received: 30.8.02, revised: 18.11.02, accepted: 5.12.02

${ }^{* *}$ Snejina Michailova, born 1965, Ph.D., Copenhagen Business School. Research areas: Crosscultural management with a focus on Russian companies with Western participation, Management in post-socialist organizations, Links between knowledge, Knowledge management and culture. Corresponding address: Michailova@cbs.dk

Kenneth Husted, born 1962, Ph.D., Copenhagen Business School. Research areas: Research management in industry and at universities, Management of knowledge creation, Knowledge sharing, Knowledge utilization in organizations and networks. Corresponding address: Husted@cbs.dk
} 


\section{Introduction}

Organisations can be seen as networks of decisions and decision makers (Choo 1998; O'Reilly et al. 1987), and management can be viewed as decision making (Monahan 2000). Decisions are the basis of action - purposes are defined, after which resources are allocated and authorized - and efficient decision making in organisations relies upon, among other things, access to relevant knowledge and the ability to process it. Consequently, organisations hostile to knowledge sharing present particular challenges to managers as decision makers.

Traditional Russian companies, e.g. those established in the Soviet period and operating in the manufacturing sector, serve as powerful examples of organisations hostile to knowledge sharing (Michailova/Husted, 2002a, 2003). Additionally, these companies usually have a highly centralized decisionmaking structure (Czinkota 1997; Lawrence/Vlachoutsicos 1990; McCarthy/Puffer 1992; Puffer/McCarthy 1993), which increases the need for bottom-up information and knowledge flows. Russian employees generally expect strong leadership (Bollinger 1994; Holden et al. 1998; Michailova 2000, 2002), and superiors are viewed as authority figures who take the important decisions. In fact, Russians feel that 'a good boss should not work, but simply sit around the office and make decisions' (Wilson/Donaldson 1996, 140). Together, knowledge sharing hostility and the need for centralized one-way knowledge flows constitute a dangerous combination for strategic decisionmaking processes. This paper analyses the interface between the different dimensions of knowledge sharing hostility and their consequences for strategic decision making.

The paper takes its conceptual starting point in two theoretical streams: the first relates to knowledge sharing hostility, while the second is associated with decision making. We focus on knowledge sharing as it relates to individual behaviour (Katz/Allen 1982; Leonard 1995; Husted/Michailova 2002b; O'Dell/Grayson 1998) and elaborate on the dimensions related to knowledge hoarding, knowledge rejection and apprehension about failures by investigating their implications for decision making. Rather than focusing on standard and routine decisions in organisations, this paper concentrates on the complex and dynamic nature of strategic decision processes as discussed by Mintzberg et al. (1976). They have proposed a process-oriented model of decision making, focusing on the stages, activities and dynamics of choice behaviours for generating multiple options and alternative solutions. In the analysis of our empirical data, the model's distinction of identification, development and selection as the three central decision-making phases is applied. 


\section{The study and its purpose}

This paper is based on empirical research from 53 interviews conducted in 25 Russian companies over the past six years. For company selection, four main criteria were used. First, companies had to be established during the Soviet period. Second, they should represent different manufacturing sectors and industries. Third, they had to be recognized as high-performing and successful companies within the local business community. In order to satisfy this criterion, the opinions of Russian experts from the business community, higher educational institutions in the field of economics, and the business media were taken into account. Revenue growth rate figures from the Russian business magazine Expert covering a period of five years were used as the quantitative criterion in identifying particularly successful companies. Fourth, regardless of whether they were operating with or without foreign involvement, companies had to be managed by Russians. All the companies studied were located in large Russian cities in the European part of the country. Therefore, these findings do not necessarily apply to companies in other parts of Russia.

All interviewees held positions at top or middle management level. The respondents' average age was 49 and all had been educated to university level or equivalent. Only five of the 53 respondents were female. All interviews, each lasting between one and two hours, were conducted in Russian, tape-recorded and transcribed verbatim.

As stated above, the empirical data used in this study were collected over a period of six years. The row data directed our attention to several key topics, which can be clustered under the umbrella of the decision-making issue. The interview data in this paper are used to illustrate analytical arguments related to the consequences of knowledge sharing hostility for the decision-making process. The data are not taken as the starting point for formulating propositions or hypotheses.

\section{Knowledge sharing hostility}

Some business environments and organisational cultures are more hostile to knowledge sharing than others (Husted/Michailova 2002b). In environments strongly hostile to knowledge sharing, additional obstacles make sharing knowledge more problematic and frequently impossible. Figure 1 presents the three dimensions of individual behaviour as related to (a) knowledge transmission, (b) knowledge reception, and (c) the substance of the specific knowledge sharing activity. 


\section{Knowledge hoarding}

Transmitter behaviour can be expressed by the willingness to share knowledge with other organisational members on request, the decision to share or hoard knowledge being largely individual. The decision to hoard knowledge is destructive from an organisational point of view but, at the same time, is often rational and justifiable from an individual perspective. In organisations that are less hostile to knowledge sharing, knowledge hoarding is mainly used as an instrument to support individual economic concerns. In organisations that are more hostile towards knowledge sharing, features such as avoidance of exposure, hoarding knowledge as a strategy for coping with uncertainty, a focus on hierarchical structures and involvement in power games are dominant. A certain philosophy, according to which people are measured by what they know and do individually, instinctively invites knowledge hoarding and perpetuates the behaviour of keeping one's cards close to one's chest. In contrast with this individualistic behaviour, organized collaboration and sharing knowledge are key words in today's successful organisations, which work towards breaking the 'knowledge is power' paradigm and instead associate power with those who, by sharing what they know, become a knowledge source.

Figure 1. Dimensions of knowledge sharing hostility (Husted/Michailova 2002b)

Mild hostility

Strong Hostility

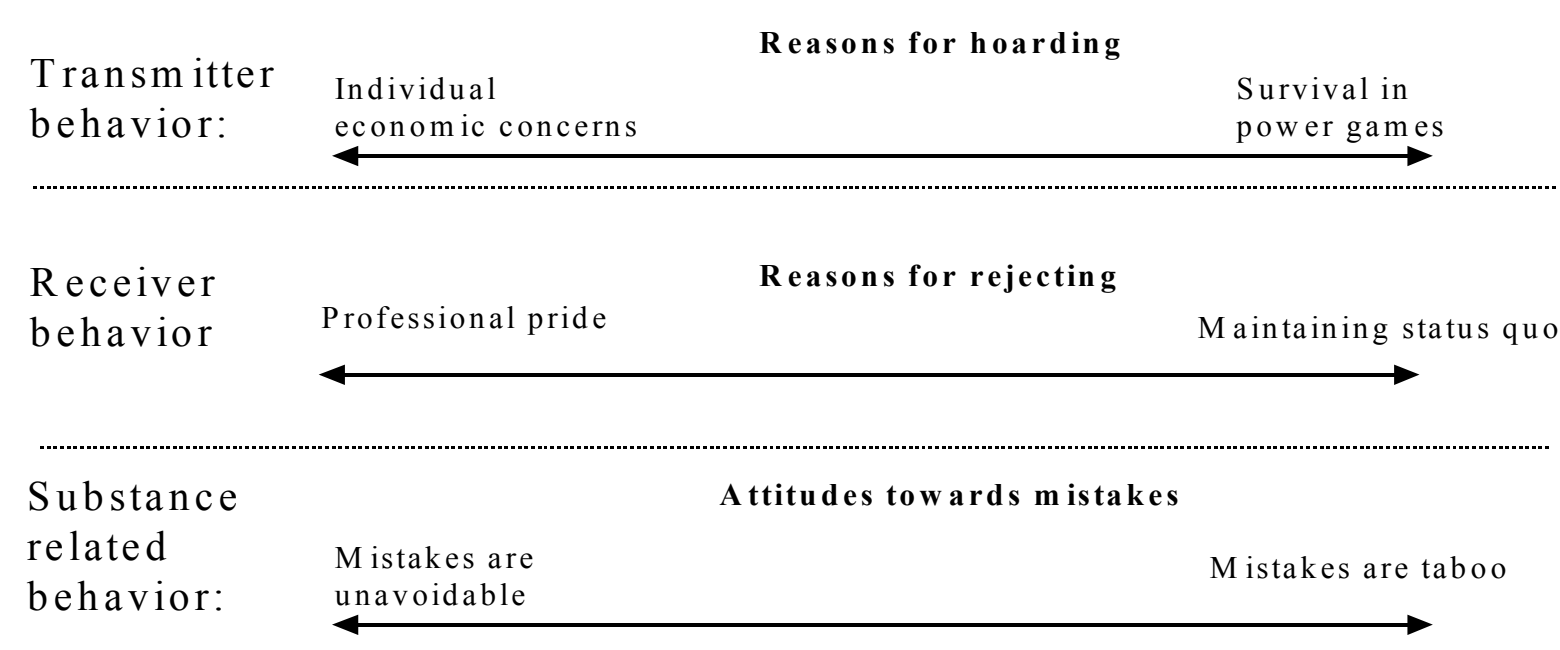

In organisations that are more hostile towards knowledge sharing, features such as avoidance of exposure, hoarding knowledge as a strategy for coping with uncertainty, a focus on hierarchical structures and involvement in power games are dominant. A certain philosophy, according to which people are measured by 
what they know and do individually, instinctively invites knowledge hoarding and perpetuates the behaviour of keeping one's cards close to one's chest. In contrast with this individualistic behaviour, organized collaboration and sharing knowledge are key words in today's successful organisations, which work towards breaking the 'knowledge is power' paradigm and instead associate power with those who, by sharing what they know, become a knowledge source.

\section{Rejecting knowledge}

Knowledge rejecting behaviour is captured in the notion of the 'Not-InventedHere' (NIH) syndrome, i.e. the resistance towards using knowledge created elsewhere (Katz/Allen 1982). Some of the main reasons for rejecting knowledge are a preference for developing individual ideas and knowledge, general doubt about the validity and reliability of the knowledge, strong group affiliation, and group thinking. In organisations less hostile to knowledge sharing, doubt concerning the validity and reliability of external knowledge and a preference for developing individual knowledge are usually associated with organisational members' professional pride. At the opposite end of the hostility continuum are those organisations that strongly desire to maintain the status quo, sometimes explicitly, but more often under the mask of minor changes.

\section{Attitudes to mistakes and failures}

Mistakes and failures have long been recognized as vital sources of insight, much too valuable to be buried and consciously kept secret (Kanter et al. 1992). Often the result of exploring unknown territory, mistakes and failures also allow for the development of new insights. These insights offer significant learning potential, especially for later expeditions into the unknown. In other words, learning from mistakes is highly valuable not only at an individual level, but also at group and organisational levels.

Organisational reality is, however, often different: individuals do not freely and openly share knowledge about the mistakes they have made. In less hostile knowledge sharing environments, mistakes are accepted as unavoidable and, within certain limits, may even be a valuable organisational asset. However, employees may still harbour doubts that prevent them from openly and freely sharing insights about their failures, mainly due to potential negative consequences in the future. In organisations that are highly hostile to knowledge sharing, mistakes and failures are taboo. They are covered up, shared only in unavoidable situations and with an absolutely unavoidable audience. In these organisations, people apply different strategies against making (or realizing) mistakes. If one makes a mistake and realizes it, the aim immediately becomes to conceal it and cast off responsibility as quickly as possible. At this higher end of knowledge sharing hostility, managers' and 
employees' ways of thinking are framed by the question 'Whom can we blame?' rather than 'What can we learn?'. Lack of action reflects extreme knowledge sharing hostility within an organisation. Traditional Russian organisations exhibit this and other features of strong knowledge sharing hostility (see Figure 1 , right column), which affects the decision-making process in these organisations.

As outlined above, Russian managers and employees share a number of characteristics as knowledge transmitters and knowledge receivers. The Russian business environment and the culture of older Russian companies, i.e. those established in the Soviet period, constitute a particularly fertile basis for strong knowledge sharing hostility (Michailova/Husted 2003). Knowledge hoarding, knowledge rejecting and negative attitudes towards making and recognizing mistakes are not merely present, but perpetuated and intensified in many Russian companies. This is also the case in the companies that participated in the present study. Independent of industry type and whether or not the respective company was operating with or without foreign involvement, the features relating to knowledge sharing hostility were common to all companies. These are the specific conditions of the framework in which the particular characteristics of the decision-making process will now be analysed.

Table 1. Decision-making in organisations hostile to knowledge sharing

\begin{tabular}{|c|c|c|c|c|}
\hline & \multicolumn{3}{|c|}{ Decision-Making Phases } \\
\hline & & Identification & Development & Selection \\
\hline 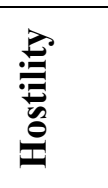 & $\begin{array}{l}\text { Knowledge } \\
\text { hoarding }\end{array}$ & \multirow[t]{2}{*}{$\begin{array}{l}\text { Slow recognition of } \\
\text { problems } \\
\text { Imprecise diagnosis }\end{array}$} & $\begin{array}{l}\text { Alternatives are not } \\
\text { ready-made } \\
\text { Memory search is } \\
\text { largely restricted }\end{array}$ & $\begin{array}{l}\text { Position-based power } \\
\text { prevents knowledge sharing } \\
\text { and consequently judgment } \\
\text { Reliance on intuition }\end{array}$ \\
\hline \multirow{2}{*}{ 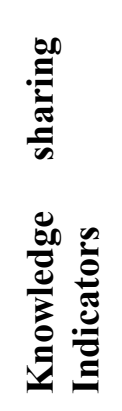 } & $\begin{array}{l}\text { Knowledge } \\
\text { rejection }\end{array}$ & & $\begin{array}{l}\text { No use of search } \\
\text { generators } \\
\text { Alternatives based } \\
\text { on external } \\
\text { knowledge are not } \\
\text { accepted }\end{array}$ & No bargaining \\
\hline & $\begin{array}{l}\text { Attitudes } \\
\text { towards } \\
\text { mistakes } \\
\end{array}$ & $\begin{array}{l}\text { Serious problems do } \\
\text { not surface }\end{array}$ & $\begin{array}{l}\text { Preference for } \\
\text { ready-made } \\
\text { solutions }\end{array}$ & \\
\hline
\end{tabular}

\section{Decision making in organisations hostile to knowledge sharing}

Decision making is a topic that has traditionally attracted the attention of management literature. Organisations are networks of decisions, decision makers and decision making (Cyert/March 1992; Hickson et al. 1986; Choo 1998; Janis/Mann 1977), and all organisational behaviour springs from decisions. Acknowledging that decision making can often occur randomly, disconnected from goals (Cohen et al. 1972) or as a result of bargaining among 
players pursuing their own interests (Allison 1971), we conceptualise decision making as a structured sequence of goal-directed problem solving. In this paper we employ the process-oriented model of decision making, which focuses on the stages, activities and dynamics of choice behaviours for generating multiple options and alternative solutions. In their ASQ article from 1976, Mintzberg et al. distinguish identification, development and selection as the three central decision-making phases. The following sections relate these three phases to the characteristics of environments hostile to knowledge sharing. The summary of this analysis is presented in Table 1 .

\section{Identification}

According to the model by Mintzberg et al. (1976), during the identification phase the need for the decision is recognized and an understanding of the decision issues is developed. The need for the decision is defined as an information need, 'a difference between information on some actual situation and some expected standard' (Mintzberg et al. 1976: 253). Consequently, identification is primarily an information and knowledge seeking activity that taps into existing knowledge bases and locates new knowledge channels.

Single-person authority, typical for many Russian companies, is closely associated with the right and responsibility to make decisions. Individual decision-making, as opposed to group/team decision-making, is the norm in those companies. A taken for granted rule is accepting the leader without question (Bronfenbrenner 1970; Pearson 1990). As pointed out by Puffer et al. (1997: 267-268), "the Russian concept of strong leadership reinforces a more authoritarian belief system for those in senior ranks, and less disposition for them to share managerial decision making with workers". Subordinates do not feel a need to challenge their superiors' power of being the sole decision makers even in relation to minor issues. Instead, they treat one-man (decision-making) authority as given, needed and vitally important (Michailova 2002: 183). Russian employees treat early involvement, showing initiative and offering suggestions at the beginning of the decision-making process differently according to whether they are dealing with Russian or Western managers (Michailova 2002). With Russian managers, they interpret such behaviour as intervening in their superior's domain, demonstrating disrespect or disloyalty towards their superior or questioning his or her abilities.

Russian organisations are generally characterized by a poor information culture (Wilson/Donaldson 1996). This goes hand in hand with a general business culture already disinclined to spend time analysing information to enable more effective decision making. According to Wilson/Donaldson (1996), information is often poorly collected or not gathered at all. Furthermore, it is inefficiently organized and often not released, either for reasons of lingering secrecy, lack of computers and other processing methods, or because of the prevailing belief 
that the public simply has no need to know. Complicating the problem is Russians' reluctance to provide information: a tradition of secrecy stemming from the past still influences people's attitudes, and standard company information such as annual reports, public relations brochures and product data is scarcely available. Managers may not know their own company's internal situation and have little more than production figures to guide them. Judging the size of a potential market, or even finding the most cost-effective contractor to supply materials for a project can be nothing more than guesswork.

The lack of employees' involvement in decision making on the one hand and the poor information culture on the other result in a slow recognition of organisational problems. When the need to make decisions is first recognized, these aspects result in an imprecise diagnosis of the problem's cause and nature. An even more dramatic consequence is the fact that serious problems remain hidden.

\section{Development}

In the development phase of the decision-making process, opportunities are elaborated on and new solutions are outlined on the basis of two clusters of routines, known as search and design routines. The model by Mintzberg et al. (1976) identifies four types of search routines: (a) search in the existing organisational memory, (b) passive search, i.e. waiting for alternatives to appear, (c) activating search generators and (d) active direct search for information about alternatives. These four types have an inbuilt progression in at least two aspects: they move from the local to the remote on the one hand, and from memory-oriented and passive to active search on the other (Cyert/March 1992). Design routines entail the complex and iterative process of developing custom-made solutions or modification of existing 'off the shelf' alternatives.

Knowledge sharing involves uncertainty about which specific pieces of idiosyncratic knowledge are to be shared with whom in order to create benefits for the organisation (Jensen/Meckling 1996). Unawareness at both ends of the transfer is a major barrier to knowledge sharing (Szulanski 1996). Potential receivers or users are often not aware of the existence of the knowledge they need and, likewise, the potential sources are not aware that there may be use for their knowledge somewhere else in the organisation. The larger the organisation, the greater the problem of unawareness. As identified by the information cost perspective (Grant 1996; Jensen/Meckling 1996), the solution to this problem is not to share all knowledge created in an organisation, but to strive to transfer relevant pieces of knowledge. However, to achieve this it is necessary to know in advance what specific knowledge is relevant to whom. Hoarding behaviour in Russian organisations reaches a level where it becomes impossible to find the exact person who holds the required information. 
According to our field data, Russian managers view the lack of transparency in who-knows-what as a major barrier to accessing the information and knowledge they need, and finding a trivial piece of information can take weeks. The lack of transparency in the location of relevant knowledge combined with resistance to knowledge sharing results in a situation where alternative ready-made solutions are not available either off the shelf or in organisational memory (see Table 1).

Formal power is highly valued in Russian organisations. However, hierarchical differences are an impediment to knowledge sharing, both top-down and bottom-up. Russian managers treat information as a source of power, status and authority rather than as a basis for making decisions. Managers are mainly occupied with seeking and receiving information, i.e., to adopt Mintzberg's (1973) vocabulary, they play a 'monitoring' informational role. At the same time, they avoid diffusion, transmission and sharing of information, i.e. play carefully a 'disseminating' informational role, which leads to engaging in the role of 'resource allocator' and 'disturbance handler' at the cost of 'negotiating' and 'acting as an entrepreneur' (Mintzberg 1973).

In Russian companies, there are usually long-lasting relationships among organisational members, making individuals feel strongly attached to a group, both formally, in terms of membership, and emotionally (Michailova 2000). This strong group affiliation, which should not be confused with team spirit, reinforces the resistance to knowledge sharing. As a consequence, Russian managers and employees tend to resist new ideas from outside because the new information and feedback could fracture the stability and familiarity of the particular group, thus upsetting the organisational order and continuity which they value and respect so highly.

This respect for formal power coupled with strong group affiliation leads to the failure to use search generators in the decision-making process. At the same time, alternatives based on external knowledge are not accepted. Environments hostile to knowledge sharing seem to prevent the inbuilt progression of search routines mentioned above. The search, in this case, is not merely local, but fragmented down to the boundaries of the group. Additionally, the search remains passive mainly because hierarchical power prevents knowledge sharing.

\section{Selection}

The selection phase of the decision-making process aims to evaluate alternatives and choose a solution. Evaluation choice routines are at the heart of this stage. These routines apply judgment (making an individual choice), bargaining (collective exercise of individual judgments) or analysis (evaluating the decisions against a cluster of criteria and making a final choice) to reach a decision. 
The majority of Russian respondents in top managerial positions perceive the distribution of power related to decision making as a zero-sum game. Naturally, they try to occupy all decision making space. They typically have difficulties delegating authority and consider discussions irrelevant. Russian employees, too, find discussions with colleagues, joint setting of priorities, developing frameworks as a team and informing one another about ongoing issues and processes as not very productive. Instead, they have developed a relatively high level of tolerating ambiguity and the skills and ability to act on the basis of insufficient and fragmented information. This is combined with an individuallyoriented work ethic according to which one gets ahead in life by self-reliance and one should avoid depending on others (Puffer et al. 1997).

Environments hostile to knowledge sharing create a weak foundation for judgment. This may partially explain why Russian managers have a tendency to make decisions based on intuition (see Table 1). Holden et al. (1998: 37) quote the conclusions of the mixed Russian-Western team of the Russian Privatisation Centre: 'Russian managers base their decisions on intuition; this approach seriously conflicts with the western approach which emphasizes the gathering and analysis of hard facts.' This observation is confirmed by the findings of a survey conducted among 170 Russian top and middle managers between 1999 and 2000. All participants in the survey were attending a Nordic Management Training Programme, conducted in Russia from 1997 to 2000, and represent a number of different Russian firms related either directly or indirectly to Nordic companies. The survey participants ranked intuition as one of the most important managerial attributes along with being energetic, analytical and well organized.

\section{Conclusion}

Most of the research on decision making is conducted by Western researchers in Western organisations, who implicitly assume culturally-bounded Western views of the world and its management processes. This paper focuses on some specificities of decision making in Russian organisations; however, rather than analysing the process per se, we have examined the way in which decision making is intertwined with knowledge sharing hostility, exploring the dimensions related to knowledge hoarding, knowledge rejection and apprehension about failures by investigating their implications for decision making as viewed in the process model.

In organisations hostile to knowledge sharing, the identification phase of decision making is characterized by employees' lack of involvement in the process on the one hand, and a poor information culture on the other. This results in a slow recognition of problems in organisations and, when the need for making decisions is first recognized, in imprecise diagnosis of the problem's cause and nature. Another negative consequence is that serious problems remain 
concealed. In the development phase, the high respect for formal power and the strong group affiliation lead to a failure to use search generators in the decisionmaking process. At the same time, alternatives based on external knowledge are not accepted. Environments hostile to knowledge sharing seem to prevent the inbuilt progression of search routines. The search, in this case, is not merely local, but fragmented down to the boundaries of the group. Additionally, the search remains passive mainly because hierarchical power prevents knowledge sharing. Finally, in the selection phase, environments hostile to knowledge sharing create a weak foundation for judgment. This may partly explain why Russian managers have the tendency to make decisions and act largely on the basis of intuition.

\section{Acknowledgements}

This paper is written in the framework of the research projects SODIAC (Sculpturing Organisational Dynamics in a Context) and MANDI (Managing the Dynamic Interfaces between Knowledge and Culture) at Copenhagen Business School, Denmark. The authors gratefully acknowledge the participation of the companies studied and the financial support of the funding companies and institutions. Part of the empirical data used in this paper was collected in cooperation with ALT Research and Consultancy, St Petersburg, Russia.

\section{References}

Allison, G.T. (1971): Essence of decision: Explaining the Cuban missile crisis. Boston, MA: Little Brown.

Bollinger, D. (1994): The four cornerstones and three pillars in the 'house of Russia' management system, in: Journal of Management Development, No. 13(2), pp 49-54.

Bronfenbrenner, U. (1970): Two worlds of childhood: U.S. and USSR. New York: SAGE.

Choo, C. (1998): The knowing organization: How organizations use information to construct meaning, create knowledge, and make decisions. New York: Oxford University Press.

Cohen, M.D./ March, J.G./Olsen, J.P. (1972): A garbage can model of organizational choice, in: Administrative Science Quarterly, No. 17(1), pp 1-25.

Cyert, R.M./March, J.G. (1992): A behavioral theory of the firm. $2^{\text {nd }}$ edition. Oxford, UK: Blackwell.

Czinkota, M.R. (1997): Russia's transition to a market economy: Learning about business, in: Journal of International Marketing, No. 5, pp 73-93.

Grant, R. (1996): Toward a knowledge-based theory of the firm, in: Strategic Management Journal, No. 17, pp 109-122.

Hickson, D.J./Butler, R.J./Cray, D./Mallory, G. R./Wilson, D.C. (1986): Top decisions: Strategic decision making in organizations. San Francisco, CA: Jossey Bass. 
Holden, N./Cooper, C./Carr, J. (1998): Dealing with the new Russia: Management cultures in collision. Chichester: John Wiley \& Sons.

Husted, K./Michailova, S. (2002a): Knowledge sharing in Russian companies with Western participation, in: International Management, No. 6(2), pp 17-28.

Husted, K./Michailova, S. (2002b): Diagnosing and fighting knowledge sharing hostility, in: Organizational Dynamics, No. 30(4), pp 60-73.

Janis, I./Mann, L. (1977): Decision making: A psychological analysis of conflict, choice, and commitment. New York: Free Press.

Jensen, M./Meckling, W. (1996): Specific and general knowledge and organizational structure, in: Myers, P. (ed.): Knowledge management and organizational design. Boston: Butterworth-Heinemann, pp 17-38.

Kanter, R.M./Stein, B.A./Jick, T.D. (1992): The challenge of organizational change: How companies experience it and leaders guide it. New York: Free Press.

Katz, R./Allen, T. (1982): Investigating the not invented here (NIH) syndrome: A look at the performance, tenure and communication patterns of $50 \mathrm{R} \& \mathrm{D}$ project groups, in: $\mathrm{R} \& \mathrm{D}$ Management, No.12(1), pp 7-19.

Lawrence, P./Vlachoutsicos, C. (1990): Behind the factory walls: Decision making in Soviet and US enterprises. Boston, MA: Harvard Business School Press.

Leonard, D. (1995): Wellsprings of knowledge. Boston, MA: Harvard Business School Press.

McCarthy, D.J./Puffer, S.M. (1992): Perestroika at the plant level: Managers' job attitudes and views on decision-making in the former USSR, in: Columbia Journal of World Business, No. 27(1), pp 86-99.

Michailova, S. (2000): Contrasts in culture: Russian and Western perspectives on organizational change, in: Academy of Management Executive, No. 14(4), pp 99-112.

Michailova, S. (2002): When common sense becomes uncommon: Participation and empowerment in Russian companies with Western participation, in: Journal of World Business, No. 37, pp 180-187.

Michailova, S./Husted, K. (2003): Knowledge sharing hostility in Russian Firms. Forthcoming in California Management Review.

Mintzberg, H. (1973): The nature of managerial work. New York: Harper \& Row.

Mintzberg, H./Raisinghani, D./Thèorêt, A. (1976): The structure of 'unstructured' decision processes, in: Administrative Science Quarterly, No. 21(2), pp 246-175.

Monahan, G.E. (2000): Management decision making. Cambridge: Cambridge University Press.

O'Dell, C./Grayson, J. (1998): If only we knew what we know: Identification and transfer of internal best practices. California Management Review, No. 40(3), pp 154-174.

O’Reilly, C./Chatman, J./Anderson, J. (1987): Message flow and decision making, in: F. Jablin et al. (Eds.), Handbook of organizational communication. Newbury Park: Sage, pp 600-623.

Pearson, L. (1990): Children of glasnost: growing up Soviet. Seattle, WA: University of Washington Press. 
Puffer, S. M./McCarthy, D.J. (1993): Decision-making authority of former Soviet and American managers: Not so different after all?, in: The International Executive, No. 35(6), pp 497-512.

Puffer, S./McCarthy, D.J./Naumov, A.I. (1997): Russian managers' beliefs about work: Beyond the stereotypes, in: Journal of World Business, No. 32(3), pp 258-276.

Szulanski, G. (1996): Exploring internal stickiness: Impediments to the transfer of best practice within the firm, in: Strategic Management Journal, No. 17, pp 27-43.

Wilson, D./Donaldson, L. (1996): Russian etiquette \& ethics in business. Chicago, IL: NTC Business Books. 